\title{
Studies on the Asiatic Charophyta III.*
}

\author{
By KOzO IMAHORI**
}

今堀宏三：束亞輪藻類小記 III

Received July 2, 1953

\section{$\S$ Two species of Nitella which produce an accessory fertile branch at the first furcation of branchlet.}

So far as the investigation made by the author is concerned, Nitella microcarpa from Surinam and $N$. flagellifera from Saharanpur only have these proliferous character, i.e. the production of fertile branches at the furcations of branchlets. Recently, he has collected two kinds of plants with outstanding character and discovered that one of them is $N$. flagellifera which has been the endemic to India and the other is a new species which he calls Nitella Tuyamae.

Nitella flagellifera Groves \& Allen in Journ. Bot., 65, 1927, p. 337 ; G. O. Allen in Journ. Ind. Bot. Soc. 7, 1928, p.59, pl. 4 ; Zaneveld in Blumea 4, 1910, p. 81.

Plants monoecious, green to dark green, $20 \sim 30 \mathrm{~cm}$ high. Stem moderately stout, $300 \sim 500 \mu$ in diameter; internodes in the lower parts $2 \sim 3$-times and in the upper parts as long as the branchlets. Fertile and sterile branchlets similar, 3-times furcate; dactyls uniformly bicellular; elongated. Occasionally an accessory fertile branch which furcate $2 \sim 3$-times, produced at the first furcation of branchlets. 우 and $\delta$ gametangia produced together at the second and third furcations, not at the first. Antheridia terminal, $230 \sim 250 \mu$ in diameter. Oogonia solitary, 500 600 $\mu$ long by $400 \mu$ broad, with 9 spiral convolutions. Oospores brown to dark brown, 300 $330 \mu$ long, $250 \sim 300 \mu$ broad with 6 ridges; membrane reticulate.

Nom. Jap.: Chinpin-hurasumo.

Hab. : in ponds, pH. 6.8.

Loc.: in Honshu-Prov. Noto ; Tokuda, Nanao City, Sept. 10, 1948, K. I. No. 1013 -Prov. Ettyu; Hukumitsu-cho, Tonami-gun, Aug. 8, 1948, K. I. No. 611-Prov. Yamashiro; Kyoto, Aug. 20, 1948, K. I. No. 611-Prov. Yamashiro; Kyoto, Aug. 20. 1948, leg. K. Kubota, K. I. No. 601.

Distr.: Asia (India-Gangetic Plain), new to Japan.

It is the most remarkable characteristic of Nitella flagellifera that it has accessory branches which are very small and produced at the first furcation. These accessory branches are found in only a few species, viz. Nitella microcarpa and $N$.

\footnotetext{
* Contribution from the Laboratory of Systematic Botany of the Faculty of Science, Kanazawa University, No. 14 .

** 金沢大学理学部植汤学教室 本研觉は交部省科学研究助成金に上るるの〉一部である.
} 
Tuyamae. But the present species differs from these by the elongated and bicellular dactyls, rather large oogonia and oospores, and reticulate oospore-membrane.

Since Dr. G, O. Allen first described this species in India, no one has been able to collect the plant of this species. It is very interesting that such uncommon and rare specimens were detected in several ponds in the far distant district, $37^{\circ} \mathrm{N}$, Japan.

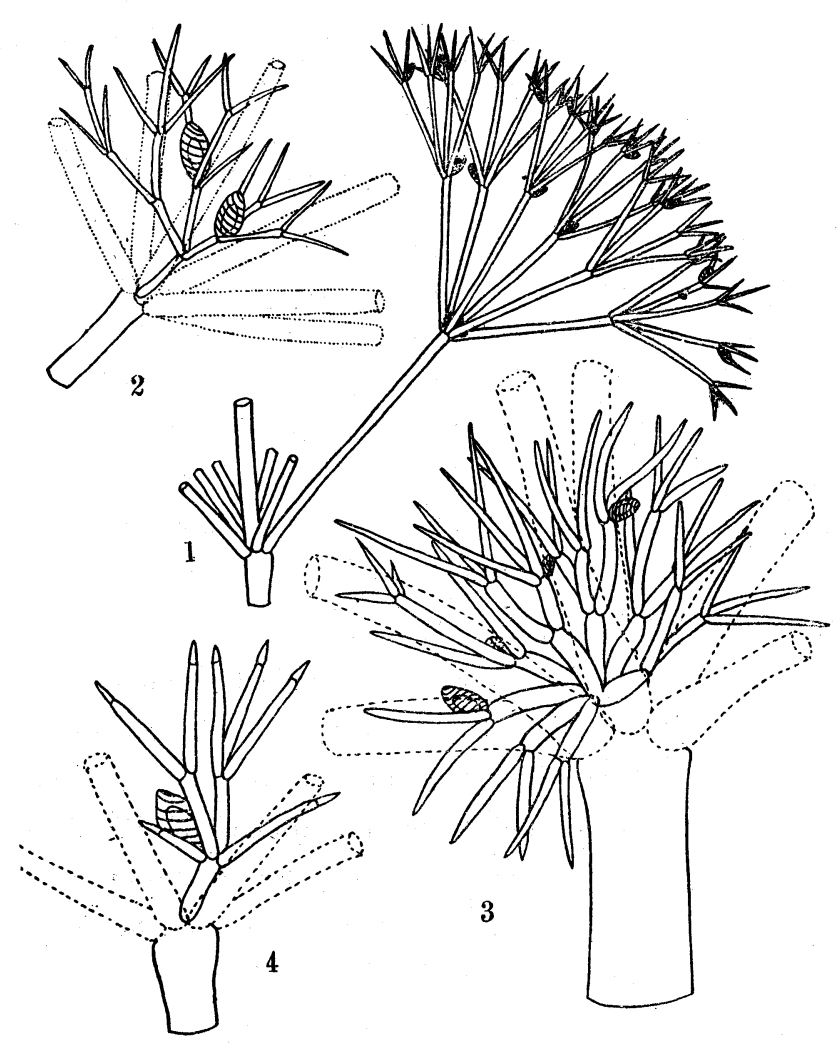

Fig. 3. Accessory branches. (1 \& 2, Nitella flagellifera Gr. et All. 3 \& 4, Nitella Tuyamae Imah.)

1. Fertile branchlet, with an accessory branch at the primary furcation, $\times 3$. 2. Accessory branch, enlarged, $\times 15$. 3. Accessary branch, produced at the base of a whorl of branchlets, $\times 30$. 4. Accessory branch produced at the first furcation of a branchlet, $\times 30$.

Nitella Tuyamae Imahori sp. nov.

Planta monoecia, $10 \sim 20 \mathrm{~cm}$ alta, claro-viridis, diaphana. Caulis tenuis, $260 \sim 300 \mu$ crassus; internodia quam ramuli 1 3-plo longiora. Verticilli fertiles et steriles similes, 3 4 tim furcati; radii primarii fere dimidium longitudinis totius ramulorum attingentes, $120 \sim 140 \mu$ crassus ; radii secundarii $6 \sim 7$; radii tertii $4 \sim 5$; radii quaternii $2 \sim 3$, quorum 1 saepe iterum in radiis $2 \sim 4$-quintis furcati; dactyli $2 \sim 4$, semper 2-cellulati, cellula ultima $40 \sim 80 \mu$ longa et basi $16 \sim 22 \mu$ lata. Verticilli 
superioribus et ad nodum primarium frequenter ramulos accessores et fertiles portantes; ramuli accessori parva, ad basi verticillorum 7 8 aggregata, ad nodum primarium solitari ; radii primarii $1 / 3 \sim 1 / 4$ totius longitudinis ramulis; radii secundarii $3-4$; radii terti $2 \sim 3$; dactyli 2 -cellulati.

우 et $\hat{\delta}$ gametangia ad nodos secundarii et tertii ramulorum ordinarium, et ad omnibus nodos ramulorum accessorium, plerumque solitaria. Antheridia $200 \sim 220 \mu$ diametro, brevistipitata. Oogonia $500 \sim 530 \mu$ longa et $300 \sim 330 \mu$ lata, cellulis spiralibus 8: coronula parva, $15 \mu$ alta et basi $50 \mu$ lata. Oospora brunnea, $280 \sim 300 \mu$ longa et $250 \sim: 80 \mu$ lata; striis alatis 7 ; membrana dense granulata.

Nom. Jap.: Tuyama-hurasumo.

Hab.: in ponds, pH 8.0, growing with Nitella Saitoiana.

Loc.: in Honshu-Prov. Inaba; Hase, Yamato-mura, Aug. 23, 1951, K. I. No. 838.

Distr.; endemic to Japan.

The most remarkable characteristic of this species is the accessory branchlets, which are produced not only at the base of whorls but also at the first furcations of the branchlets, and by this characteristic the present species is easily distinguishable from the all other resembling species which belong to the section "Heteroclemae". The new name is chosen to express the author's thanks to Dr. T. Tuyama, who gave me kind advice and criticism.

\section{§ On the species "Nitella laxa T.F. Allen".}

Dr. T.F. Allen established Nitella laxa as an independent species. He distinguished $N$. laxa from $N$. flexilis only by the larger habit and grumous membrane of oospores of the former. But the decoration of oospore membrane shows no difference between these plants, because, though those membrane of Nitella flexilis seem quite smooth, the outer opaque layer conceals the inner grumous layer. Consequently, there is no doubt that $N$. laxa must be identified with $N$. flexilis var. longifolia.

Nitella flexilis Agardh, in Syst. Alg. 1824, p. 124; Imahori in Sci. Rep. Kanaz. Univ. 1, 1951, p. 210.

var. longifolia Braun apud Migula in Rabenhorst. Krypt. Fl. Deutchl. ed. 2, Characeen, 1897, p. 137 ; ibid., in Hedwigia 70, 1930, p. 211; Wood in Farlowia 3, 1948, p. 349 .

Syn. Nitella laxa Allen in Bull. Torrey Bot. Club, 23, 1896, p. 533 (fide Imahori); Makino in Journ. Jap. Bot. 6, 1929, pp. 373, 379, 380.

Plants $30 \sim 40 \mathrm{~cm}$ high, very flexible and translucent, bright green. Stem stouter than typical form, ca. $500 \sim 800 \mu$ in diameter: intcrnodes as long as to $2 / 3$ the length of branchlets. Fertile and sterile branchlets similar, 6 8 in a whorl, once divided. Dactyls $1 \sim 3,1 / 3 \sim 1 / 4$ the length of the primary rays, at the apex abruptly pointed.

Antheridia and oogonia produced together. Antheridia $400 \sim 500 \mu$ in diameter. Oogonia solitary or geminate, $700 \sim 800 \mu$ long, $580 \sim 620 \mu$ wide with $8 \sim 9$ spiral convolutions. Oospore dark brown to black, $450 \sim 600 \mu$ long, $400 \sim 500 \mu$ wide with 6 
prominent ridges; membrane quite similar to that of typical form.

Nom. Jap.: Oh-hurasumo.

Hab.: in ponds and swamps, $\mathrm{pH}$ 6.5 7.1, occasionally growing with Nitella furcata.

Loc.: in Hokkaido-Prov. Kushiro; Hamanaka-mura, Sept. 29, 1951, K.I. Nos. 989990. in Honshu-Prov. Rikuzen; Takadate-mura, Natori-gun, Nov. 10, 1950, K. I. No. 783-Prov. Kaga ; Kasadani-mura, Kahoku-gun, Oct. 12, 1917, K. I. No. 530 Prov. Inaba; Hase, Yamato-mura. Aug. 23, 1951, K. I. No. 936-Prov. Yamashiro; Yakushiji pond, Kyoto (by Allen 1896)-Prov. Bizen; Gokan (by Migula, 1930).

in Kyushu-Prov. Bungo; Marunuma, Imazu, Shimoge-gun, Aug. 14, 1951, K. I. No. 848.

Distr.: Asia, Europe, North America.

The variety of this plant is distinguished from the typical form by the elongated branchlets, larger, stouter habit and its bright greenish color. The plant generally grows so abundantly as to give a bushy appearance in the fields.

$\S$ A new species "Nitella Allenii".

Since Dr. T.F. Allen had described a plant as "Nitella subglomerata var. japonica", no one has been able to recollect or redescribed this plant, the author was lucky enough to detect and study this alga, and detected that the plant must be an independent species.

Nitella Allenii Imahori, sp. nov.

Syn. Nitella subglomerata A. Braun var. japonica Allen in Bull. Torrey Bot. Club, 22, 1895, p.69; Makino in Journ. Jap. Bot. 6, 1929, p. 373. Jap.

Planta monoecia, $15 \sim 25 \mathrm{~cm}$ alta, zonatim incrustata, obsucuriviridis. Caulis flexilis, $\quad 0.4 \sim 0.5 \mathrm{~mm}$ diametro; internodia et ramuli vulgo aequilonga. Verticilli fertiles quam steriles paulum breviores, plus minus congesti. Verticillorum ramuli steriles $6 \sim 8,1.5 \sim 2 \mathrm{~cm}$ longi, duplicato furcati ; radii primarii $3 / 5$ totius longitudinis ramulorum ; radii secundarii $4 \sim 5$; radii tertiarii $2 \sim 3$. Verticillorum ramuli fertiles 6, gymnocephali, duplicato furcati; radii primarii $1 / 2$ totius longitudinis ramulorum; radii secundarii $3 \sim 4$; radii tertiarii $2 \sim 3$. Dactyli ramulorum sterilium eis fertilium similes, semper unicellulati, acuminati.

ㅇ et $\hat{\delta}$ gametangia ad nodos omnes. Antheridia terminalia, ca. $200 \mu$ diametro. Oogonia plerumque aggregata, parva, constanter $260 \sim 270 \mu$ longa, $210 \sim 220 \mu$ lata, cellulis spiralibus 7 , apices versus elongatis ; coronula delapsa, $35 \mu$ alta, ad basin $40 \mu$ lata. Oospora subglobosa, atro-brunnea, $200 \sim 220 \mu$ longa, 180 200 $\mu$ lata; striis 5, multo alatis; membrana anguloso-reticulata.

Nom. Jap.: Allen-hurasumo.

Hab.: in ponds, $\mathrm{pH} 7.2$.

Loc.: in Honshu-Mikawa; Seishin pond (by Allen, 1895)-Prov. Kii; Kasugajinja, Ikeda-mura, June 8, 1943, K. I. Nos. 553, 554 (Type specimen No. 553).

Distr.: endemic to Japan. 
This plant resembles Nitella acuminata var. subglomerata in its appearance, but there are too many and significant differences between them to be identified as the same species. The present species has branchlets which regularly twice furcate, and oospores which are very small, with strongly reticulate decoration on their membranes.

It is a very remarkable characteristic of this plant that the dactyls are uniformly 1-celled in spite of twice-furcation of their branchlets. The flanged ridges of oospores are also found in those of Nitella acuminata var. subglomerata, though those ridges of the present species are less in number. The plant which the author collected, shows well marked annular incrustations of calcium carbonate.

$\S$ New locality of Nitella confervacea.

Nitella confervacea is distributed widely in Europe and some other continents,

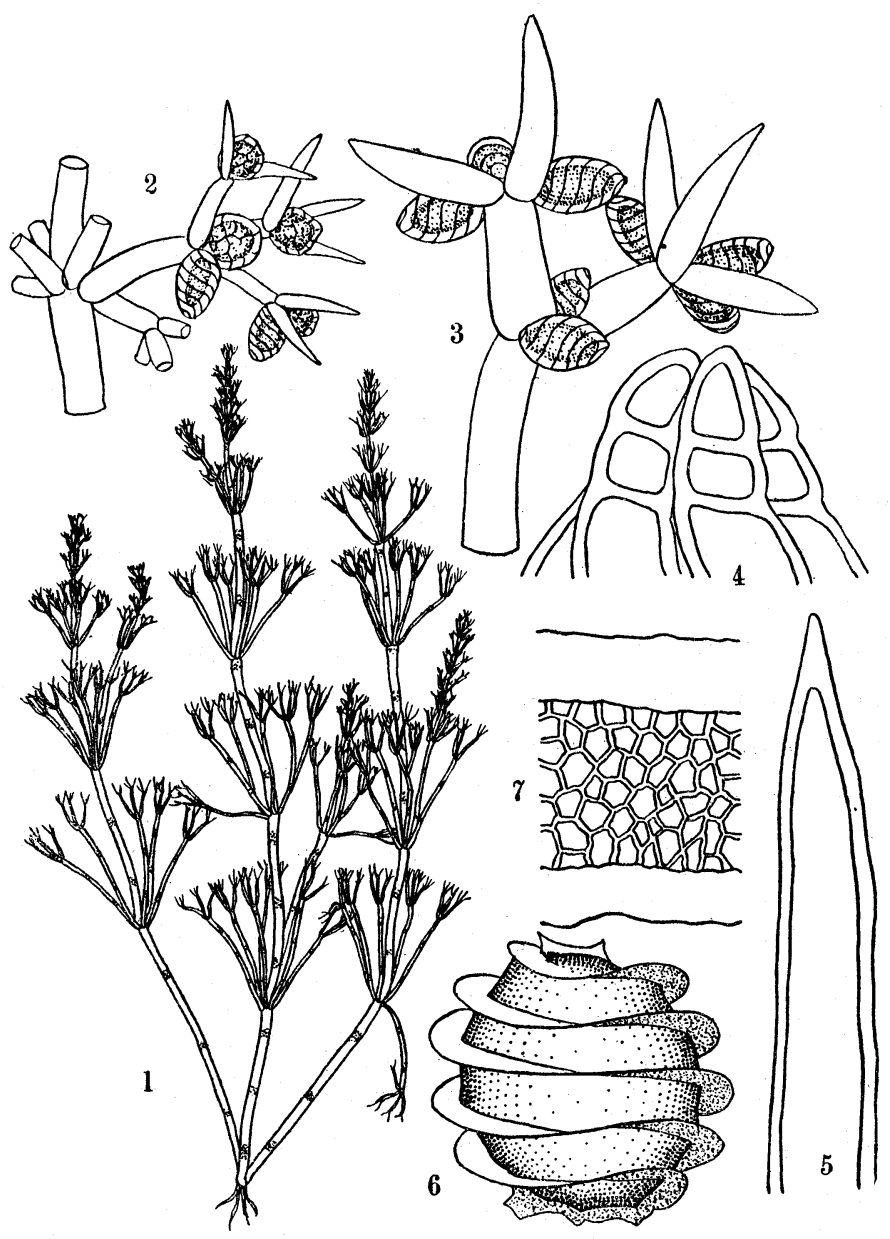

Fig. 4. Nitella Allenii Imahori

1. Plant, $\times \frac{1}{2}$ 2. Young fertile branchlet with antheridia and unripe oogonia, $\times 19$. 3. Matured fertile branchlet with ripe oogonia, $\times 19$. 4. Coronula, $\times 300$ 5. A part of a dactyl, $\times 19$. 6. Oospore with flanged ridges, $\times 75$. 7. Reticulate oospore-membrane, $\times 300$. 
but it is a very unusual plant, as is pointed out by Dr. J. Groves. The author could collect a specimen of the present species which was growing in a pond in Kyushu.

Nitella confervacea A. Braun, Consp. Syst. Charac. Europ., 1867, p. 2; Braun \& Nordstedt in Abh. Koen. Akad. Wiss. Berlin, 1882, pp. 12, 64 ; Migula, Die Characeen, 1890, p. 182 ; Wood in Bot. Rev. 18, 1952. p. 332.

Syn. Nitella Nordstedtiana H. \& J. Groves in Journ. Bot. 28, 1890, p. 67 ; Wood in Farlowia 3, 1948, p. 380.

Chara batrachosperma Thuiller, accord. to Reichenbach, Iconograph. Bot. 8, 1830, p. 794.

Nitella batrachosperma (Reichenbach) A. Braun, Neue Denkschr. Schweiz. Gesell. Naturw. 10 (3), 1847, p. 10; Braun \& Nordstedt in Abh. Koen. Wiss. Berlin, 1882, pp. 12, 66; Migula, Die Charac., 1890, p. 184; J. Groves \& Bullock-Webster, Brit. Charoph., 1, 1920, p. 124 ; J. Groves in Journ. Linn. Soc. Bot., 46, 1924, pp. 367 ; G. O. Allen in Jonrn. Bombay Nat. Hist. Soc. 30, 1925, p. 597 ; ibid., in Journ. Ind. Bot. Soc., 7, 1928, p. 58 ; Pal in Journ. Linn. Soc., Bot., 49, 1932, pp. 64, 71 ; Zaneveld in Blumea 4, 1940, p. 80; Daily in Butler Univ. Bot. Stud. 6, 1944, p.154; Olsen in D. Kgl. Dansk. Vidensk. Selskab, Biol. Skrifter. 3, 1944, p. 40.

Plants monoecious, graceful, slender and small, up to $5 \mathrm{~cm}$ high. Internodes 2 3 times the length of branchlets. Sterile and fertile branchlets similar, $6 \sim 8$ in a whorl, 2 3-times furcate; primary rays half to one third the length of the entire branchlets; secondary rays $4 \sim 6$, shorter than each of the other ray; tertiary rays 3 5, of which 1 2 furcate once more. Dactyls 2 5, elongated, uniformly 2-celled. $\phi$ and $\delta$ gametangia produced at the first and second furcations, solitary or conjunct, occasionally covered with thick mucus crowd. Antheridia $180 \sim 220 \mu$ in diameter. Oogonia solitary, $380 \sim 430 \mu$ long (incl. coronula) by $300 \sim 330 \mu$ wide, showing $9 \sim 10$ spiral convolutions; coronula rather small, $30 \sim 35 \mu$ high and $40 \sim 45 \mu$ wide. Oospore yellowish to dark brown, $270 \sim 300 \mu$ long, $250 \sim 270 \mu$ wide, with $7 \sim 8$ prominent ridges ; membrane first finely granulate, and later tending to become definitely reticulate.

Nom. Jap.: Ko-hurasumo.

Hab.: in ponds, pH 7.4, occasionally growing with Chara Braunii, C. Benthamii and rarely with Chara corallina.

Loc.: in Kyushu-Prov. Chikuzen; Kasuga-mura, Tsukushi-gun, Aug. 20, 1951, K. I. No. 978.

Distr.: Asia (India, Burma), Europe, North America and Australia, new to Japan.

The very slender and small habit, remote nodes of branchlets and elongated dactyls give this species a very distinct appearance, and it can never be mistaken for any of the other Japanese Nitellae, with the exception of Nitella gracillima. But this species differs from the $N$. gracillima by the fertile primary furcations of branchlets, larger o spores and finely granulate membranes of oospores. The ridges of oospore are more flanged than those of the English specimen, but as prominent as those of German specimen, which were described and figured by Dr. W. Migula (1897, p 187), 